\title{
PENGEMBANGAN MULTIMEDIA INTERAKTIF BERBASIS COMPUTER ASSISTED INSTRUCTION (CAI) PADA MATA PELAJARAN AKUNTANSI PERBANKAN SYARIAH
}

\author{
Riris Ariska ${ }^{1}$, Luqman Hakim ${ }^{2}$ \\ ${ }^{1}$ Universitas Negeri Surabaya, ${ }^{2}$ Universitas Negeri Suarabaya \\ 1ririsariska303030@gmail.com, ${ }^{2}$ luqkmanhakim@unesa.ac.id
}

\begin{abstract}
The learning paradigm in Indonesia continues to experience shifts to improve the quality and relevance of education. To realize the learning paradigm that currently applies, the government as a central institution seeks to perfect the curriculum. The current education curriculum in Indonesia is the 2013 curriculum. Learning in the 2013 curriculum uses a scientific approach to improve student activity and interactivity. Interactive multimedia based on Computer Assisted Instruction (CAI) one of learning media that can increase the activeness and interaktivity of students, so that learning becomes more effective and effecient. The drill and practice format on CAI is suitable for subjects that require understanding of concepts and mastery of skills such as Syariah Banking Accounting. The purpose of this research is to analyze the development process, the feasibility, and the responses of students to interactive multimedia based the Computer Assister Instruction (CAI) in Syariah Banking Accounting. This type of research is a research and development with the ADDIE development model of Reiser and Mollenda which consists of five stages including analysis, design, development, implementation and evaluation. The results showed the average percentage obtained from the validation of material experts by $86,56 \%$ with the criteria "very feasible", evaluation experts by $87,22 \%$ with the criteria "very feasible", media experts by 93,52\% with the criteria "very feasible", and the response of students by 97,21\% with the criteria "very good". The overall results of the validation of the experts and the response of students obtained an average percentage of $91,13 \%$ so it can be concluded that the interactive multimedia that was developed is very feasible to use in learning and get a very good response from students.
\end{abstract}

Keywords: interactive multimedia, Computer Assisted Instruction (CAI), Syariah Banking Accounting

\section{Pendahuluan}

Abad ke-21 merupakan abad yang menjadi transisi perubahan masyarakat industri menjadi masyarakat berbasis pengetahuan yang memengaruhi berbagai aspek kehidupan. (Wijaya, 2016:265). Dalam masa pengetahuan, masyarakat yang bekerja dituntut untuk menjadi pekerja yang memiliki pengetahuan. Menurut Trilling dan Hood (Wijaya, 2016:265) pendidikan saat ini harus mengadakan suatu perubahan guna menghasilkan pekerja baru yang dibutuhkan pada masa pengetahuan ini. Perubahan tersebut dapat dimulai dengan menyusun kembali paradigma pendidikan yang sudah diterapkan (Kemendikbud, 2018:9). Paradigma pendidikan merupakan suatu dasar dalam menentukan kebijakan dan pelaksanaan pendidikan untuk mengatasi permasalahan dalam dunia pendidikan (BNSP, 2010:7). Badan Nasional Standar Pendidikan (BNSP) pada 2010 merumuskan "Paradigma Pendidikan Nasional Abad XXI" untuk menjawab tantangan-tantangan baru dalam dunia pendidikan. Dengan demikian, tumbuhlah pergeseran paradigma dalam pembelajaran untuk meningkatkan kualitas dan relevansi pendidikan (Kemendikbud, 2018:12) Pemerintah sebagai lembaga sentral berupaya mewujudkan pendidikan yang dibutuhkan abad ke-21, salah satunya melalui pengembangan kurikulum (Pamungkas, 2017:2).

Kurikulum 2013 adalah langkah lanjut dari pengembangan kurikulum KTSP 2016 (Andrian \& Rusman, 2019:15). Dalam kurikulum 2013, pembelajaran lebih difokuskan kepada peserta didik. Pembelajaran yang berfokus pada peserta didik dapat memberikan dampak yang positif bagi perkembangan belajarnya (Wright, 2011:95-96). Selain itu, pendekatan ilmiah (scientific approach) diisyaratkan sebagai sebuah pendekatan baru untuk membiasakan peserta didik berpikir seperti ilmuan (Sufairoh, dalam Andrian \& Rusman,

DOI: 10.33603/ejpe.v9i1.4161

This is an open access article under the CC-BY-SA license 
2019:15). Pendekatan tersebut ditujukan untuk meningkatkan keaktifan dan interaktifitas peserta didik dalam memperoleh ilmu pengetahuan dari berbagai sumber. Keaktifan merupakan fakor penting untuk mewujudkan pembelajaran yang berfokus pada peserta didik (Kim \& Davies, 2014:17). Peserta didik dapat lebih aktif dengan pemakaian media pembelajaran di kelas (Ratnasari, 2018:1-12).

Guru dapat memakai media pembelajaran untuk menyalurkan materi pembelajaran kepada peserta didiknya (Kurniawan, 2018). Penggunana media pembelajaran dapat meningkatkan minat dan keinginan, membangunkan motivasi, merangsang proses pembelajaran, serta memberi efek psikologi kepada peserta didik (Hamalik dalam Arsyad, 2017:56). Pengkombinasian beberapa media menjadi satu diperlukan untuk dapat memaksimalkan fungsi media dalam pembelajaran. Kombinasi beberapa media pembelajaran yang ditampilkan dalam bentuk dokumen untuk menyajikan informasi oleh Roblyer \& Doering (2013:172-173) disebut sebagai multimedia. Keberadaan multimedia dalam pembelajaran dapat meningkatkan keikutsertaan dan minat peserta didik (Barzegar dkk, 2012: 1263). Menurut Munir (2012:128) salah satu katagori multimedia adalah multimedia interaktif, yaitu suatu multimedia yang memungkinkan pemakai melakukan apapun yang diinginkan untuk langkah berikutnya. Multimedia interaktif dapat meningkatkan kemandirian peserta didik dalam mendapatkan pelajaran di kelas (Munir, 2012:136). Oleh sebab itu, perlu dipertimbangkan pemakaian multimedia interaktif yang yang efektif dan efisien di dalam kelas.

CAI (Computer Assisted Instruction) merupakan multimedia interaktif yang efektif dan efisien apabila digunakan sebagai media pembelajaran di dalam kelas (Iqbal dalam Sedega dkk, 2017:46). Menurut Anderson dalam (Fahrozi, 2018:3) CAI adalah pembelajaran yang melibatkan peserta didik bersinggungan langsung dengan komputer untuk menyalurkan materi pembelajaran maupun latihan soal, dan mengetes perkembangan peserta didik dalam penguasaan materi dan mengerjakan latihan soal. Menurut Dangwal \& Khare (2016:35) pemanfaatan komputer dapat memfasilitasi peserta didik yang pelan maupun cekatan dalam memproses pelajaran yang diterima dengan cara yang lebih individul sesuai kecepatan dalam memahami pelajaran dan mengerjakan latihan. Selain itu, penyajian materi dengan berbagai cara (teks, audio, dan grafik) dapat menjadikan CAI sebagai media pembelajaran yang menarik dan efektif (Vernadakis dkk, 2005:99). Menurut Arsyad (2017:124) pengunaan CAI sebagai media pembelajaran dapat membangkitkan peserta didik untuk menyelesaikan latihan yang dikarenakan kedapatan animasi, gambar, atau irama. Menurut Bhaskar \& Mathur (2015:51) CAI dapat memberikan kesempatan belajar mandiri dan evaluasi mandiri kepada peserta didik melalui format CAI yaitu drill and practice. Drill and practice merupakan salah satu format CAI yang menyajikan pembelajaran yang lebih difokuskan pada latihan dan praktik (Nazimuddin, 2015:186). Latihan disajikan sesudah pemaparan materi pembelajaran, kemudian diteruskan dengan praktik pengerjaan soal yang dapat diulang-ulang. Pengerjaan secara berulang-ulang dapat meningkatkan kecepatan dan keterampilan peserta didik dalam mengerjakan soal (Rahman, 2019:7). Selain itu, format drill and practice dapat memberikan tanggapan langsung berupa penilaian, sehingga tingkat pemahaman peserta didik terhadap materi ajar dapat diketahui secara mandiri (Roestiyah, 2011:127). Format ini cocok digunakan untuk memahami konsep dan menguasai keterampilan.

Akuntansi Perbankan Syariah (APS) merupakan mata pelajaran yang memerlukan pemahaman konsep dan penguasaan keterampilan (Ratih \& Hakim, 2018:161). Kombinasi dari teori-teori akuntansi, kemudian unsur perbankan dari pengumpulan dana sampai penyaluran dana yang semunya dilakukan berdasarkan prinsip-prinsip syariah. Isi materinya dapat dikatakan lengkap karena bersifat teoritis yang dilanjutkan dengan praktik. APS 
merupakan mata pelajaran produktif pada kompetensi keahlian Perbankan Syariah yang tergolong baru di SMK, sehingga guru pengampunya membutuhkan berbagai sumber belajar untuk menunjang pembelajaran di dalam kelas.

Kegiatan studi pendahuluan yang dilakukan peneliti pada aplikasi layanan konten digital menghasilkan informasi bahwa beberapa multimedia interaktif sebagai media pembelajaran untuk berbagai jenjang pendidikan. Berdasarkan analisis peneliti, beberapa multimedia interaktif sebagai media pembelajaran telah menunjang penerapan Kurikulum 2013 dengan menyajikan video sebagai bahan pengamatan, materi pelajaran, dan evaluasi. Akan tetapi, multimedia interaktif sebagai media pembelajaran yang telah ada hanya sedikit yang ditujukan untuk peserta didik pada jenjang pendidikan SMK. Selain itu, masih banyak multimedia pembelajaran interaktif yang belum memiliki soal yang bertipe HOTs (Hight Order Thinking Skill) pada bagian evaluasinya. Studi pendahululuan juga dilakukan dengan mewawancarai guru APS di SMKN 2 Kota Mojokerto yang diperoleh informasi bahwa sekolah tersebut telah dilengkapi fasilitas laboratorium komputer yang telah mencukupi. Namun, guru Perbankan Syariah belum memanfaatkan laboratorium tersebut secara penuh, khususnya dalam mata pelajaran Akuntansi Perbankan Syariah kelas XII. Meskipun pembelajaran telah menggunakan kurikulum 2013, namun guru masih menjadi pusat dalam pembelajaran. Di sisi lain, guru memberikan fotokopi buku pegangan guru atau menuliskan materi dari buku pegangan guru di whiteboard untuk menyampaikan materi pembelajaran, sehingga pembelajaran belum mampu meningktakan keaktifan peserta didik dalam mencari informasi dan memecahkan masalah. Selain itu, menurut bebepara peserta didik kelas XII Perbankan Syariah, meraka terkadang merasa bosan ketika penyampaian materi hanya melalui penjelasan guru dan peserta didik menyalin materi yang ditulis guru di whiteboard. Soal-soal yang diberikan oleh guru juga kurang bervariasi, karena guru hanya memberikan soal-soal dalam bentuk fotokopi dari buku cetak yang menjadi pegangan guru, sehingga peserta didik kekurangan soal latihan untuk menunjang kompetensi peserta didik dalam pemecahan masalah. Sehingga diperlukan media pembelajaran yang menyediakan soal-soal yang lebih banyak untuk meningkatkan kompetensi peserta didik dalam pemecahan masalah.

Berdasarkan permasalahan di atas, maka dibutuhkan pengembangan multimedia interaktif berbasis CAI menggunakan format drill and practice yang dapat membantu guru dalam memberikan soal-soal yang lebih bervariasi. Multimedia interaktif berbasis CAI yang akan dikembangkan memiliki kelebihan-kelebihan seperti ringkasan materi sebagai tambahan dalam mengumpulkan informasi, dan soal latihan dalam bentuk studi kasus, soal evaluasi dalam bentuk pilihan ganda, serta soal true or false yang dapat digunakan pada fase menalar untuk digunakan secara individu maupun berkelompok. Soal evaluasi dan true or false dalam format drill and pactice disusun secara acak setiap kali dipergunakan, sehingga memungkinkan multimedia interaktif tersebut dipergunakan lebih dari satu kali dengan soalsoal yang berbeda susunannya untuk setiap kali dipergunakan. Soal latihan, evaluasi dan true or false dalam multimedia interaktif bertipe HOTs (Hight Order Thinking Skill). Soal-soal yang bertipe HOTs merupakan pembeda produk yang akan dikembangkan dengan yang ada di pasaran.

Pengembangan multimedia interaktif berbasis CAI menunjukkan hasil yang layak dan baik untuk dipakai dalam kegiatan belajar mengajar. Sejalan dengan penelitian Vika Yulia Widarsih (Vika, 2018:1-8) menunjukkan bahwa pengembangan multimedia memperoleh hasil penilaian dari para validitor dengan rerata $92,85 \%$ yang dinyatakan "sangat layak". Dan rerata prosentase dari respon peserta didik 93,5\% yang dinyatakan "sangat baik". Selanjutnya dari penelitian Ken Yuanita Pamungkas (2019) menunjukkan bahwa pengembangan multimedia interaktif berbasis CAI memperoleh penilaian dari para validitor 
dan peserta didik dengan rerata prosentase $94,5 \%$ yang memiliki keterangan sangat layak dan baik untuk dipakai dalam kegiatan belajar mengajar.

Peneliti ingin menjalankan peneiltian pengembangan yang berjudul "Pengembangan Multimedia Interaktif Berbasis Computer Assisted Instruction (CAI) pada Mata Pelajaran Akuntansi Perbankan Syariah" yang dilatarbelakangi oleh fakta-fakta yang telah dijelaskan sebelumnya. Rumusan masalah untuk menjawab penelitian ini yaitu bagiamana proses pengembangan, kelayakan, dan respon peserta didik terhadap multimedia interaktif berbasisis Computer Assisted Instruction (CAI) pada mata pelajaran Akuntansi Perbankan Syariah?. Sehingga tujuan dari penelitian ini yaitu untuk menganalisis proses pengembangan, kelayakan, dan respon peserta didik terhadap multimedia interaktif berbasis Computer Assisted Instruction (CAI) pada mata pelajaran Akuntansi Perbankan Syariah.

\section{Metode Penelitian}

Metode Penelitian ditulis tanpa sub judul. Metode penelitian dalam naskah menjelaskan mengenai pendekatan, lokasi penelitian, metode, pupulasi dan sampel, teknik pengumpulan data, dan teknik analisis data.

Jenis penelitian ini adalah pengembangan atau Research and Development yang akan dijalankan dengan mengikuti model pengembangan dari Reiser dan Mollenda yaitu model pengembangan ADDIE. Prosedurnya terdiri atas analysis, design, develop, implementation, dan evaluation untuk menghasilkan multimedia interaktif berbasis CAI pada mata pelajaran Akuntansi Perbankan Syariah yang akan dinilai oleh ahli materi, ahli evaluasi, ahli media, dan 20 peserta didik. Data yang digunakan merupakan data kualitatif dan kuantitatif. Data kualitatif adalah data berupa kata-kata yang dikumpulkan menggunakan angket terbuka berupa lembar telaah para ahli (Riduwan, 2012:5). Selanjutnya, lembar telaah dari para ahli dikaji secara kualitatif untuk memperbaiki kualitas produk yang dikembangkan hingga tercapai kelayakan. Sedangkan data kuantitatif adalah data yang berupa bilangan angka yang diperoleh dari angket tertutup berupa lembar validasi para ahli dan angket respon peserta didik (Riduwan, 2012:5). Lembar validasi para ahli mengadaptasi rentang penilaian dari Skala Likert tang terdapat pada Tabel 1. Sedangkan angket respon peserta didik menggunakan Skala Guttman pada Tabel 2 untuk penilainya.

Tabel 1. Kriteria Penilaian Skala Likert

\begin{tabular}{|l|c|}
\hline \multicolumn{1}{|c|}{ Kriteria } & Nilai \\
\hline Sangat Baik & 5 \\
\hline Baik & 4 \\
\hline Sedang & 3 \\
\hline Tidak Baik & 2 \\
\hline Sangat Tidak Baik & 1 \\
\hline
\end{tabular}

Sumber: Riduwan (2012:17) 
Tabel 2. Kriteria Penialaian Skala Guttman

\begin{tabular}{|l|c|}
\hline \multicolumn{1}{|c|}{ Jawaban } & Nilai/Skor \\
\hline Ya & 1 \\
\hline Tidak & 0 \\
\hline
\end{tabular}

Sumber: Riduwan (2012:17)

Keseluruhan lembar validasi dan angket respon peserta didik dihitungan dengan cara membagi jumlah skor total dengan skor maksimal tiap variabel, lalu dikalikan $100 \%$. Hasil perhitungan tersebut akan menghasilkan kesimpulan mengenai layak atau baik tidaknya multimedia interaktif yang dikembangakan. Multimedia tersebut dapat dikatakan layak atau baik, apabila perolehan prosentase $\geq 61 \%$ dengan kriteria interpretasi yang tercantum pada tabel berikut:

Tabel 3. Kriteria Interpretasi

\begin{tabular}{|c|l|}
\hline Prosentase & \multicolumn{1}{|c|}{ Kriteria Interpretasi } \\
\hline $0 \%-20 \%$ & Sangat Tidak Layak/ Tidak Baik \\
\hline $21 \%-40 \%$ & Tidak Layak/Tidak Baik \\
\hline $41 \%-60 \%$ & Cukup Layak/Cukup Baik \\
\hline $61 \%-80 \%$ & Layak/Baik \\
\hline $81 \%-100 \%$ & Sangat Layak/Sangat Baik \\
\hline
\end{tabular}

Sumber: Riduwan (2012:17)

\section{Hasil dan Pembahasan}

\section{Proses Pengembangan Multimedia Interaktif}

Multimedia interaktif dengan mengikuti model pengembangan ADDIE dari Reiser dan Mollenda yang terdiri dari lima tahapan yang dimulai dengan tahap analisis (analysis). Langkah pertama dari tahap analisis yaitu analisis kinerja. Berdasarkan hasil analisis kinerja yang dilakukan peneliti dengan mewawancarai guru Akuntansi Perbankan Syariah di SMKN 2 Kota Mojokerto dan wawancara terbuka dengan beberapa peserta didik, didapatkan keterangan bahwa pemanfaatan media pembelajaran di kelas belum dimaksimalkan, khususnya pada mata pelajaran Akuntansi Perbankan Syariah (APS). Guru masih menggunakan whiteboard dan memberikan modul dalam bentuk fotokopi untuk memberikan materi dan soal, pemberian materi melalui whiteboard membuat peserta didik merasa bosan dalam memperoleh pengetahuan, pemberian soal dalam bentuk fotokopi membuat peserta didik kekurangan soal latihan untuk menunjang keterampilan pemecahan masalah dan pembelajaran masih berpusat kepada guru, sehingga keaktifan peserta didik dalam mencari informasi pada mata pelajaran APS masih rendah. Langkah kedua dari tahap analisis yaitu analisis kebutuhan. Hasil analisis kebutuhan menunjukkan bahwa masih dibutuhkan media pembelajaran untuk meningkatkan keaktifan peserta didik dalam memperoleh informasi, 
meningkatkan keterampilan penyelesaian masalah, serta mengetahui tingkat pemahaman terhadap materi ajar APS secara mandiri. Langkah ketiga dari tahap analisis yaitu perumusan tujuan pembelajaran yang diturunkan dari kompetensi inti dan kompetensi dasar untuk menyusun isi dan desain multimedia interaktif yang akan dikembangkan. Tahap ini menghasilkan tujuan pembelajaran pada mata pelajaran APS kelas XII semester 1 yang terdiri dari tujuh kompetensi dasar.

Tahap kedua model pengembangan dari Reiser dan Mollenda yaitu tahap desain (design). Tahap ini diawali dengan kegiatan praproduksi yang dilakukan dengan cara menyusun materi yang akan dimasukan dalam multimedia interaktif yang terdiri dari valuta asing, kartu ATM, kartu kredit syariah, travellers cheque, safe deposite box, letter of credit, bank garansi, pembiayaan salam, dan pembiayaan istishna' yang diindentifikasi dari materi pokok pada silabus dan tujuan pembalajaran. Kemudian, dilanjutkan dengan menyusun soal latihan yang berbentuk studi kasus yang disertai lembar kerja bagi peserta didik, soal evaluasi yang berbentuk pilihan ganda, dan soal true or false yang berbentuk sebab-akibat. Langkah kedua dari tahap desain yaitu penyusunan rancangan naskah (stroryboard) dan pengumpulan konten aplikasi. Penyusunan rancangan naskah (storyboard) dilakukan untuk memberikan gambaran atau alur terhadap tampilan multimedia interaktif yang akan dikembangkan. Kemudian, konten aplikasi seperti musik instrumen, tombol, dan gambar dikumpulkan dengan cara dibuat sendiri atau diunduh dari berbagai sumber open source. Setelah kebutuhan konten aplikasi terpenuhi, selanjutnya tampilan didesain menggunakan Adope Photoshop dan Adope Ilustrator. Sehingga multimedia interaktif berbasis CAI untuk mata pelajaran Akuntansi Perbankan Syariah terdiri atas tampilan halaman pembuka, menu utama, petunjuk penggunaan, menu materi, sub menu materi, pendahuluan, materi pembelajaran, soal latihan, soal evaluasi, soal true or false, dan profil pengembang.

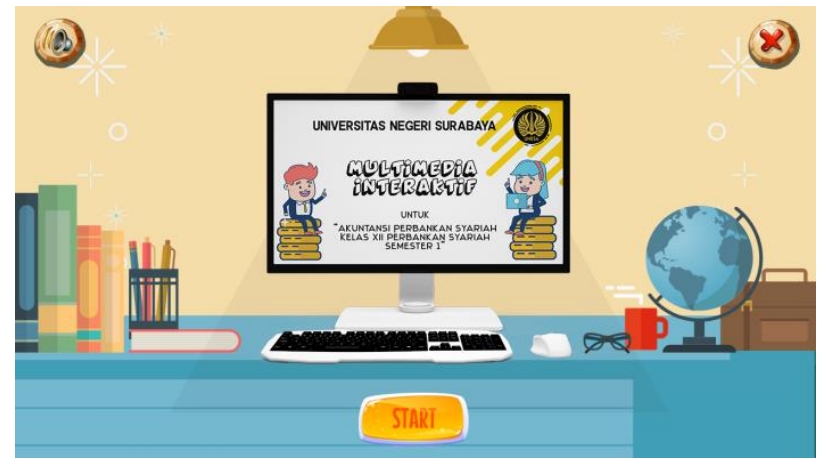

Gambar 1. Halaman awal

Tahap ketiga model pengembangan dari Reiser dan Mollenda yaitu tahap pengembangan (development). Pada tahap ini, isi multimedia interaktif yang telah dibuat pada kegiatan praproduksi dimasukkan ke dalam tampilan-tampilan yang telah didesain dengan menggunakan Adope Photoshop dan Adope Ilustrator. Selanjutnya, semua tampilan disusun menggunakan Construct 3 yang direalisasikan menjadi multimedia interaktif (Draf I). Selain itu, peneliti juga menyusun buku pendamping bagi pengguna yang berisi acuan penggunaan multimedia interakif dan lembar kerja soal latihan. Multimedia interaktif (Draf I) diserahkan kepada para ahli untuk mendapatkan saran dan masukan. Selanjutnya, multimedia interaktif (Draf I) diperbaiki untuk menghasilkan multimedia interaktif (Draf II). Multimedia interaktif (Draf II) diberikan kembali kepada para ahli untuk mendapatkan penilaian dengan tujuan mengetahui kelayakannya. Tahap pengembangan pada penelitian ini menghasilkan 
multimedia interaktif berbasis CAI pada mata pelajaran Akuntansi Perbankan Syariah kelas XII semester 1 dengan rerata kelayakan dari seluruh ahli sebesar $89,10 \%$ yang dinyatakan "sangat layak" karena prosentasenya $\geq 81 \%$.

Tahap keempat model pengembangan dari Reiser dan Mollenda yaitu tahap implementasi (implementasion). Multimedia interaktif yang dinyatakan layak dipakai dalam kegiatan belajar mengajar dilakukan uji coba kepada 20 peserta didik kelas XII Perbankan Syariah di SMKN 2 Kota Mojokerto. Uji coba ini dilakukan dengan cara mengirim file multimedia interaktif, buku pedoman penggunaan, serta angket respon peserta didik secara online. Kegiatan ini menghasilkan tanggapan dari peserta didik terhadap produk yang dikembangkan.

Tahap kelima atau terakhir model pengembangan dari Reiser dan Mollenda yaitu tahap evaluasi (evaluation). Kegiatan evaluasi terdapat dalam semua tahapan yang disebut dengan evaluasi formatif. Sedangkan evaluasi di akhir dilakukan dengan menginterpetasikan respon peserta didik melalui analisis kuantitatif. Berdasarkan analisis tersebut, multimedia interaktif berbasis CAI pada mata pelajaran Akuntansi Perbankan Syariah memperoleh rerata prosentase sebesar 97,21\% dinyatakan "sangat baik" untuk dipakai dalam kegiatan belajar mengajar karena telah memperoleh prosentase lebih besar dari $81 \%$.

\section{Kelayakan Multimedia Interaktif}

Kelayakan multimedia interaktif didapatkan dari analisis dan interpretasi validasi para ahli. Interpretasinya berpatokan pada kriteria kelayakan menurut Riduwan (2012:17). Validasi materi ditujukan untuk mendapatkan penilaian tentang keyalakan materi yang terdapat dalam multimedia interaktif berbasis CAI. Validator materi dalam penelitian ini yaitu Dr. Luqman Hakim, M.SA dan Arikaweku Ckrisna, S.Pd, M.Pd. Perhitungan rerata setiap variabel dari lembar validasi dua orang ahli materi tercantum dalam Tabel 4.

Tabel 4. Hasil Analisis Validasi Ahli Materi

\begin{tabular}{|c|c|c|c|c|}
\hline No & Variabel & $\begin{array}{l}\text { Skor } \\
\text { Total }\end{array}$ & Prosentase & Kriteria \\
\hline 1 & $\begin{array}{l}\text { Kualitas isi dan } \\
\text { tujuan }\end{array}$ & 63 & $88 \%$ & Sangat layak \\
\hline 2 & $\begin{array}{l}\text { Kualitas instruk- } \\
\text { sional }\end{array}$ & 52 & $86,67 \%$ & Sangat layak \\
\hline 3 & Kualitas teknis & 43 & $85 \%$ & Sangat layak \\
\hline \multicolumn{3}{|c|}{$\begin{array}{l}\text { Rerata keseluruhan variabel } \\
\text { validasi ahli materi }\end{array}$} & $86,56 \%$ & Sangat layak \\
\hline
\end{tabular}

Sumber: Diolah oleh Peneliti (2020)

Berdasarkan tabel 4, kelayakan multimedia interaktif dari segi materi mendapatkan rerata dengan prosentase $86,56 \%$ dengan kriteria "sangat layak". Hal ini dapat diinterpretasikan bahwa materi yang disajikan dalam multimedia interaktif telah sesuai dengan tujuan pembelajaran dan didukung desain yang menarik, sehingga dapat memberikan bantuan belajar kepada peserta didik baik pembelajaran di sekolah maupun pembelajaran mandiri. Riduwan (2012:17) berpendapat bahwa prosentase $81 \%$ hingga 100\% dapat dikatakan "sangat layak". Sehingga materi yang disajikan dalam multimedia interaktif dapat digunakan untuk mencari informasi pada pembelajaran Akuntansi Perbankan Syariah kelas XII semester 1. Multimedia interaktif yang dikembangkan merupakan media pembelajaran 
yang menarik dan efektif, karena multimedia interaktif ini menyajikan materi dengan berbagia cara (teks dan grafik). Pernyataan tersebut serupa dengan pendapat Vernandakis dkk (2005:99) bahwa penyajian materi dengan berbagai cara seperti (teks, audio, dan grafik) dapat menjadikan komputer sebagai media dalam belajar yang menarik dan efektif. Materi pembelajaran di komputer disajikan secara urut, agar pembelajaran menggunakan CAI tetap efektif (Clark dalam Wahyuni, 2016:118). Multimedia interaktif yang dikembangkan juga dapat meningkatkan kemandirian peserta didik dalam memperoleh pengetahuan, karena multimedia interaktif ini menyajikan materi yang dapat diakses sewaktu-waktu. Pendapat tersebut didukung oleh Munir (2012:136) yang menyatakan bahwa multimedia interaktif dapat melatih peserta didik untuk meningkatkan kemandirian dalam memperoleh pengetahuan. Pemanfaatkan komputer untuk belajar dapat mengakomodasi kecepatan belajar peserta didik baik yang pelan maupun cekatan sesuai dengan kemampuan dalam memahami materi pembelajaran, karena peserta didik memiliki akses untuk mengatur kecepatan belajarnya (Arsyad, 2017:120; Dangwal \& Khare, 2016:35).

Kelayakan soal-soal yang disajikan dalam produk yang dikembangan didapatkan dari validasi ahli evaluasi. Ach. Yasin, S.Pd., MSEI selaku validator evaluasi memberikan penilaian terhadap tiga variasi soal yang dibuat oleh peneliti dan penilaian tersebut akan diinterpetasikan kelayakannya. Hasil analisis validas ahli evaluasi tercantum pada tabel berikut ini:

Tabel 5. Hasil Analisis Validasi Ahli Evaluasi

\begin{tabular}{|c|l|c|c|c|}
\hline No & Variabel & $\begin{array}{c}\text { Skor } \\
\text { Total }\end{array}$ & Prosentase & Kriteria \\
\hline 1 & $\begin{array}{l}\text { Kualitas isi } \\
\text { dan tujuan }\end{array}$ & 26 & $86,67 \%$ & Sangat layak \\
\hline 2 & $\begin{array}{l}\text { Kualitas } \\
\text { instruk- } \\
\text { sional }\end{array}$ & 18 & $90 \%$ & Sangat layak \\
\hline 3 & $\begin{array}{l}\text { Kualitas } \\
\text { teknis }\end{array}$ & 17 & $85 \%$ & Sangat layak \\
\hline \multicolumn{2}{|l|}{ Rerata keseluruhan variabel } \\
validasi ahli evaluasi
\end{tabular}

Sumber: Diolah oleh Peneliti (2020)

Tabel 5 menunjukkan multimedia interaktif yang dinilai dari segi evaluasi memperoleh rerata prosentase $87,22 \%$ yang dikatakan "sangat layak" yang berarti bahwa soal latihan, soal evaluasi, dan soal true or false untuk latihan dan praktik dapat meningkatkan keterampilan peserta didik dalam mengerjakan soal. Selain itu, format drill and practice dalam multimedia interaktif ini dapat memberikan umpan balik berupa penilaian, sehingga pemahaman materi setiap peserta didik dapat diketahui secara mandiri melalui soal evaluasi dan soal true or false. Roestiyah (2011:127) memiliki pendapat yang sama yaitu format drill and practice menyediakan umpan balik berupa penilaian, sehingga pemahaman materi setiap peserta didik dapat diketahui secara mandiri. Multimedia interaktif ini menyediakan tes dengan umpan balik berupa penilaian yang disajikan setelah materi pembelajaran. Hal ini sesuai dengan pendapat Gagne dkk (2005:216-221) bahwa multimedia harus dapat memberikan materi pelajaran yang jelas dan tes berserta umpan baliknya. 
Ahli media yang memberikan penilaian terhadap multimedia interaktif ini yaitu Dr. Agung Listiadi, S.Pd., M.Ak. Penilaian tersebut dapat menggambarkan kelayakan produk yang dikembangakan sebagai media yang akan digunakan dalam pembelajaran. Lembar validasi ahli media diperoleh rerata perhitungan pada setiap variabel sebagai berikut:

Tabel 6. Hasil Analisis Validasi Ahli Media

\begin{tabular}{|c|l|c|c|c|}
\hline No & Variabel & $\begin{array}{c}\text { Skor } \\
\text { Total }\end{array}$ & Prosentase & Kriteria \\
\hline 1 & $\begin{array}{l}\text { Kualitas isi } \\
\text { dan tujuan }\end{array}$ & 18 & $90 \%$ & Sangat layak \\
\hline 2 & $\begin{array}{l}\text { Kualitas } \\
\text { instruk- } \\
\text { sional }\end{array}$ & 19 & $95 \%$ & Sangat layak \\
\hline 3 & $\begin{array}{l}\text { Kualitas } \\
\text { teknis }\end{array}$ & 43 & $95,56 \%$ & Sangat layak \\
\hline $\begin{array}{l}\text { Rerata keseluruhan variabel } \\
\text { validasi ahli media }\end{array}$ & $93,52 \%$ & Sangat layak \\
\hline
\end{tabular}

Sumber: Diolah oleh Peneliti (2020)

Variabel kualitas isi dan tujuan pada Tabel 6 menunjukan rerata dengan prosentase 90\% yang dinyatakan "sangat layak" karena telah memenuhi aspek ketepatan, kepentingan, keseimbangan, dan kesesuaian. Rerata prosentase variabel kualitas instruksional yaitu 95\% yang dinyatakan "sangat layak", sehingga dapat diinterpretasikan bahwa konsep multimedia interaktif memberikan motivasi belajar untuk peserta didik. Variabel kualitas teknis dengan rerata prosentase $93,52 \%$ dinyatakan "sangat layak" yang berarti bahwa desain yang menarik pada multimedia interakif ini dapat merangsang peserta didik untuk mencari informasi dan mengerjakan latihan karena adanya animasi, gambar dan irama yang menambah realisme. Menurut Riduwan (2012:17) porsentase $\geq 81$ dapat dikatakan "sangat layak".

\section{Respon Peserta Didik}

Multimedia interaktif berbais CAI diuji cobakan kepada 20 peserta didik kelas XII Perbankan Syariah di SMKN 2 Mojokerto. Dalam kegiatan uji coba, peserta didik diberikan pengarahan secara online mengenai cara mengoperasikan multimedia interaktif yang dilanjutkan dengan pengisian angket respon peserta didik melalui google form yang telah dibagikan guna mendapatkan tanggapan terhadap multimedia interaktif berbasis CAI. Kemudian, hasil respon peserta didik dihitung dan mendapatkan hasil sebegai berikut: 
Tabel 7. Hasil Analisis Respon Peserta Didik

\begin{tabular}{|c|l|c|c|c|}
\hline No & Variabel & $\begin{array}{c}\text { Skor } \\
\text { Total }\end{array}$ & Prosentase & Kriteria \\
\hline 1 & $\begin{array}{l}\text { Kualitas isi } \\
\text { dan tujuan }\end{array}$ & 18 & $96,67 \%$ & Sangat layak \\
\hline 2 & $\begin{array}{l}\text { Kualitas } \\
\text { instruk- } \\
\text { sional }\end{array}$ & 19 & $98,75 \%$ & Sangat layak \\
\hline 3 & $\begin{array}{l}\text { Kualitas } \\
\text { teknis }\end{array}$ & 43 & $96,22 \%$ & Sangat layak \\
\hline $\begin{array}{l}\text { Rerata keseluruhan variabel } \\
\text { respon peserta didik }\end{array}$ & $97,21 \%$ & Sangat layak \\
\hline
\end{tabular}

Sumber: Diolah oleh Peneliti (2020)

Multimedia interaktif berbasis CAI memperoleh rerata prosentase 97,21\% yang dinyatakan "sangat baik". Percobaan penggunaan ini sejalan dan bahkan lebih baik dari uji coba media CAI yang dilakukan oleh Vika Yulia Widarsih dengan memperoleh rerata prosentase 93,5\%. Dengan demikian, produk yang dikembangkan dapat dikatakan sangat baik untuk dipakai dalam proses belajar mengajar, karena telah memperoleh rerata dengan prosentase $\geq 81 \%$. Multimedia interkatif juga dikatakan "sangat baik" digunakan dalam pembelajaran karena dapat meningkatkan minat dan motivasi peserta didik untuk belajar (Barzegar dkk, 2012:1263; Chen \& Chung, 2011:921). Pembelajaran dengan multimedia interaktif berbasis CAI dapat memberikan kesempatan belajar mandiri dan evaluasi mandiri kepada peserta didik (Bhaskar \& Mathur, 2015:51). Pembelajaran mandiri dapat dilakukan oleh peserta didik melalui menu materi pembelajaran. Sedangkan menu soal evaluasi dan soal true or false dapat digunakan untuk evaluasi mandiri yang keduanya memberikan umpan balik berupa penilaian.

\section{Simpulan}

Berdasarkan hasil dan pembahasan yang telah dijabarkan, maka ditarik beberapa simpulan sebagai berikut: (1) pengembangan multimedia interakif berbasis Computer Assisted Instruction (CAI) pada mata pelajaran Akuntansi Perbankan Syariah dilaksanakan menggunakan model pengembangan ADDIE dari Reiser dan Mollenda yang terdiri dari lima tahapan yaitu analysis, design, development, implementation, dan evaluation; (2) kelayakan multimedia interakif berbasis Computer Assisted Instruction (CAI) pada mata pelajaran Akuntansi Perbankan Syariah memperoleh prosentase kelayakan secara keseluruhan dengan kriteria "sangat layak"; dan (3) Multimedia interakif berbasis Computer Assisted Instruction (CAI) pada mata pelajaran Akuntansi Perbankan Syariah memperoleh respon dari peserta didik dengan kriteria "sangat baik".

\section{Referensi}

Andrian, Y., \& Rusman. (2019). Implementasi Pembelajaran Abad 21 dalam Kurikulum 2013. Jurnal Penelitian Ilmu Pendidikan, 12(1), 14-23. 
Arsyad, A. (2017). Media Pembelajaran. Jakarta: Rajawali Pers.

Badan Standar Nasional Pendidikan. (2010). Paradigma Pendidikan Nasional di Abad 21. Jakarta: Badan Standar Nasional Pendidikan.

Barzegar, N., dkk. (2012). The Effect of Teaching Model Based on Multimedia and Network on the Student Learning (Case Study: Guidance Schools in Iran). Procedia Social and Behavioral Sciences, 47, 1263-1267.

Bhaskar, \& Mathur, M. (2015). Effect of Computer Assisted Instruction (CAI) in Learning Geography Concepts at Senior Secondary Stage. Bartiyam International Journal of Educational \& Research, 4(3), 47-51.

Chen, Y. C., \& Chung, W. L. (2011). Research on the Learning Effects of Multimedia Assisted Instruction on Mandarin Vocabulary for Vietnamese Students: a Preliminary Study Involving E-Learning System. Educational Research Reviews, 6(17), 919-927.

Dangwal, K. L., \& Khare, S. (2016). Computers Assisted Instruction in Refining The Quality of Teaching and Learning. TechnoLearn: An International Journal of Educational Technology, 6(2), 35-43.

Fahrozi, C. F. A. (2018). Pengembangan Media Computer Assisted Instruction (CAI) pada Mata Pelajaran Geografi Materi Dinamika Atsmosfer Untuk Siswa Kelas X IPS di SMA Negeri 2 Bojonegoro. Jurnal Mahasiswa Teknologi Pendidikan, 9(2), 1-12.

Gagne R.M., dkk. (2005). Principles of Instruction Design, 5th Edition. Orlando: Harcourt Brace Jovanovich Publisher.

Kemendikbud. (2018). Peningkatan Proses Pembelajaran Dan Penilaian Pembelajaran Abad 21 Dalam Meningkatkan Kualitas Pembelajaran SMK. Jakarta: Direktorat Pembinaan Sekolah Menengah Kejuruan, Direktorat Jenderal Pendidikan Dasar dan Menengah, Kementerian Pendidikan dan Kebudayaan.

Kim, A. K., \& Davies, J. (2014). A Teacher's Perspective on Student-Centered Learning: Towards the Development of Best Practice in an Undergraduate Tourism Course. Journal of Hospital, Leisure, Sport and Tourism Education, 14(1), 6-14.

Kurniawan, M. R. (2018). Pengembangan Media Pembelajaran Interaktif Menggunakan Aplikasi Adobe Flash CS 6 Berbasis Android pada Materi Perdagangan Internasional Kelas XI IPS SMA. Universitas Negeri Surabaya.

Munir. (2012). Multimedia Konsep \& Aplikasi dalam Pendidikan. In Antimicrobial agents and chemotherapy (Vol. 58). Bandung: CV Alfabeta.

Nazimuddin, S. K. (2015). Computer-Assisted Instruction (CAI): A New Approach in the Field of Education (pp. 186-188). pp. 186-188. International Journal of Scientific Engineering and Research.

Pamungkas, K. Y., \& Listiadi, A. (2017). Pengembangan Media Interaktif Berbasis Computer Assisted Instruction ( CAI ) Jenis Drill And Practice sebagai Media Pembelajaran Penunjang Kurikulum 2013 pada Materi Akuntansi Kas Kecil Kelas XI Akuntansi di SMKNegeri 1 Surabaya. Jurnal Pendidikan Akuntansi, 9(2), 1-7.

Rahman, A. (2019). Pengembangan Media Pembelajaran Berbasis Web Menggunakan Model Drill and Practice. Pendidikan Dan Pengajaran, 1(2), 1-17. 
Ratih, N. P., \& Hakim, L. (2018). Pengembangan Buku Ajar Berbasis Pendekatan Saintifik sebagai Bahan Ajar Mata Pelajaran Akuntansi Perbankan Syariah pada Siswa SMK Kompetensi Keahlian Perbankan Syariah. Jurnal Pendidikan Akuntansi, 6(2), 160166.

Ratnasari, A. (2018). Meningkatkan Keaktifan dan Hasil Belajar Siswa melalui Media Pembelajaran Berbasis Modul Interaktif Adobe Flash CS6 pada Materi Jurnal Penyesuaian Kelas X Akuntansi di SMK Negeri 1 Boyolali. Portal Publikasi Ilmiah UMS, 1-12.

Riduwan. (2012). Dasar-Dasar Statistika. Bandung: Alfabeta.

Roblyer, M., \& Doering, A. D. (2013). Integrating Education Technology Into Teaching. New York: Pearson Education, Inc.

Roestiyah, N. K. (2011). Strategi Belajar Mengajar. Jakarta: Rineka Cipta.

Sari, Q. E. S., \& Listiadi, A. (2019). Pengembangan Media Pembelajaran Interaktif Menggunakan Adope Flash CS 6 pada Mata Pelajaran Akuntansi Perpajakan Kelas XI di SMK Negeri 2 Buduran. Jurnal Pendidikan Akuntansi, 07(03), 494-498.

Sedega, B.C., D. (2017). Effect of Computer Assisted Instruction (CAI) on Senior High School Students' Achievement at Pie Chart and Histogram in Core Mathematics. European Centre for Research Training and Development, 5(9), 45-68.

Vernadakis, N., dkk. (2005). The Use of Computer-Assisted Instruction in Preschool Education: Making Teaching Meaningful. Early Childhood Education Journal, 33(2), 99-104.

Vika, Y. W. (2018). Pengembangan Media CAI (Computer Assissted Instructional) pada Materi Teorema Pythagoras untuk Mata Pelajaran Matematika Kelas Viii di Smpn 2 Taman Sidoarjo. Jurnal Mahasiswa Teknologi Pendidikan, 9(2), 1-8.

Wahyuni, S. (2016). Development of Computer Assisted Instruction (CAI) Based Teaching Materials in Junior High School. International Journal of Learning and Teaching, 2(2), 117-120.

Wijaya, E. Y., Sudjimat, D. A., \& Nyoto, A. (2016). Transformasi Pendidikan Sebagai Tuntutan Pengembangan Sumber Daya Manusia di Era Global. Seminar Nasional Pendidikan Matematika 2016 Universitas Kanjuruhan Malang, 1, 263-278.

Wright, G. B. (2011). Student-Centered Learning in Higher Education. International Journal of Teaching and Learning in Higher Education, 23(3), 92-97. 